\title{
A Study of Impact of Housing Quality on the Low-income Households in Uyo, Nigeria
}

\author{
Okey Nwanekezie $^{1^{*} \quad \text { Stanislaus Okeahialam }}{ }^{2}$ \\ 1.Department of Estate Management, University of Uyo, P.M.B. 1017, Uyo, Akwa Ibom State, Nigeria \\ 2.Department of Estate Management, Imo State University, P.M.B. 20401, Owerri, Imo State, Nigeria
}

\begin{abstract}
The work seeks to examine the impact of low-quality housing on the low-income households in Uyo. Carrying out a survey, of a cross-section of 380 families in Uyo, through stratified random sampling, got 294 representing $77.37 \%$ effective responses.h Frequency count and simple percentages were used to analyze the resultant data. The study found that poverty and joblessness are the leading cause of the respondents living in low-quality housing. It also found that these respondents encountered environmental problems such as poor garbage collection, poor drainage, water pollution, air pollution and liquid waste. The study further revealed that the respondents suffered several ecological related diseases such as malaria, cough, typhoid, diarrhea and eye infection. The survey among other issues recommended the upgrading of these areas through urban renewal programmes and embarking on social housing for the low-income earners in the state.
\end{abstract}

Keywords: Housing, Low-income, households, urbanization

DOI: $10.7176 / \mathrm{JESD} / 10-8-03$

Publication date: April $30^{\text {th }} 2019$

\section{INTRODUCTION}

Housing is central to daily lives of every individual, as people spend about $70 \%$ of their time inside a residence (Ross, Parsons and Vallas, 2016). It is not just a roof over one's head; People need a home which is warm and dry, safe and free from infestation. In 1948 the universal declaration of Human Rights recognized the right to decent housing as a fundamental human right. In America, more than 30 million housing units have significant physical or health hazards, such as dilapidated structures, inadequate heating, damaged plumbing, gas leaks or lead. Globally, one-fifth of the world's population do have inadequate housing, while many children die daily because of lack of proper housing, with the majority in the developing world (Cheserek and Opata, 2011). Though statistics are unavailable on Nigerian housing condition, the housing quality of the urban population is not ideal. Nigerian urban centers have shanties, make-shift buildings, etc. (Jiboye, 2011 and Basorun and Fadairo, 2012).

Aduwo, Edewor, and Eziyi (2016) associated poverty with poor housing in Nigerian urban centers and deterioration of the environment with its attendant effects of high concentration of people, uncontrolled growth and development, poor planning and poor implementation of social housing. Inadequate housing and unsanitary living conditions with environmental degradation and decadence that stems from unchecked growth and development are also present. (Koleoso and Adeyinka, 2006). The relationship between housing and health is still subject of ongoing research with attempts to identify the different evidence, fragmented between different disciplines together. Some of the studies, however, is with a health warning on the quality of evidence, which draws attention to confounding factors; that is people in inadequate shelter suffer deprivations that assessing anyone risk factor is almost impossible.

Studies have shown that indoor allergens, notably dust mites can exacerbate or cause asthma and overcrowding to be responsible for lower respiratory tract infection (Ndarni and Angbo, 2014). A study of Ross et al. (2016) which used an objective measure of housing quality which included heating, wall and ceiling surfaces, but not dampness specifically, and the condition of structures such as stairs, found that there was a connection between adverse housing conditions and poor psychological health. Housing affects not only physical health but also social well-being. Some estimates suggest that the direct and indirect healthcare costs associated with housingrelated illnesses or injuries are in the billions of dollars. Thus, the unique place of housing in contributing to sustainable communities.

The demand for housing especially residential apartments in Uyo far outweigh the supply as is the case in most urban centers in Nigeria. Whenever the need is higher than the amount, the price is forced up, thus resulting in high rentals which the low-income earner cannot afford. The lack of social housing for the low income in Uyo has exacerbated the situation, leading to the development of informal, semi-permanent structures being occupied by the low pay as houses. This study, therefore, seeks to examine the impact and effect of poor housing quality on the low-income group in Uyo.

\section{Review of Related Literature}

The literature on housing for the low-income exist, as several authors have studied its supply, financing, strategies, etc., while the study on the impact of housing quality on the low-income household is quite a few. The concern of 
this section is to review few of the available related literature on housing quality and low-income family. In Enugu, Ononugbo, Akpan, Osho and Kritsonis (2010) examined whether income, education, gender, family size and high house rent contribute to the Enugu residents decision to dwell in the slums of Agangwu, Ngele-effor, Ugwu-Aaron, and Ugwu-Bottle. A survey design was adopted, with the distribution of a questionnaire to 400 residents of Enugu. ANOVA was used to test the three formulated hypotheses. The study concluded that the lowincome groups could not afford rent for a house in the city due to their low monthly salary (contributed by their educational background), large family size and strict government rules on land/housing. It also concluded that residents of this slum area visit the hospital frequently due to the constant suffering of diarrhea, measles, and cholera. In contrast to the above conclusions, the tested hypotheses revealed that there is no significant difference between the income and education levels of the Enugu residents and those of slum residents and their decision to live in slum areas. It could be inferred from the hypotheses testing that those living in the slum areas choose to like there without any constraints or compulsion. This study has pitfalls which result in the incorrect assumptions testing. The sample size of 400 is not representative of the population of the study area of Enugu, and the choice of the 400 residents is not probabilisticnature. The nature of data gathered from the attached questionnaires is nonparametric in life, while a parametric statistical tool of ANOVA is used to test the hypotheses. Thus, the incorrect result from the incorrect application of mathematical technique. Therefore, its' findings not representative of the actual situation in Enugu metropolis.

In a study of housing problems of low-income households, Cheserek and Opata (2011) in Kenya surveyed a cross-section of 230 heads of household in three low-income area of Langas, Huruma, and Kamukunji. Using stratified random sampling as sample technique, frequency tables, percentages, and graphs were used to analyze the gathered data. The findings revealed that low-income housing impacted negatively on human health and the environment. Health problems identified include malaria, typhoid, and cholera, while environmental issues include congestion, house pests, poor drainage, wastewater, air pollution and garbage. The study further showed that government policy is inadequate and mechanisms for enforcement are lacking, thus responsible for the housing problems of low-income groups. The study advocated for collaboration between government and property developers to ensure that the necessary facilities and environmental infrastructures such as piped water, sanitation collection, and disposal of waste are provided to alleviate the health and ecological problems of the low-income households. The findings of this study are quite relevant to the present study but in another country. Therefore a similar study needs to be conducted in Nigeria to have a holistic view of the housing problems of the low-income households.

Jiboye (2011) in an exploratory paper examines current challenges of urbanization and the housing situation in Nigeria. The author opined that urbanization process is irreversible in Nigeria and providing a useful housing policy framework constitutes one of the primary instruments required for sustainable urbanization. The paper outlined Nigerian government involvement in the housing to include state housing which achieved a limited degree of success, provision of staff quarters and the construction of many housing estates in the country. In an attempt to further address the housing deficit in the country, the government also set-up mortgage finance organizations such as the Federal Mortgage Bank and licensed primary Mortgage institutions (PMI) to mobilize savings and supply funds for housing development and also formulated the National Housing Policy. The author submitted that the housing policies and programmes of the government have achieved little, thus calling for further public sector intervention. He believes that the current dire situation can change through concerted efforts at ensuring sustainability of the programmes on the ground, new initiatives yet unexplored and demonstration of the right political will. The findings and conclusions are the author's personal opinion since no field study or experiment was undertaken to collaborate on other views.

Basorun and Fadairo (2012) in Ado-Ekiti examine the activities and challenges of Ekiti state government in housing the poor in Ado-Ekiti within the framework of the policies on housing reform in Nigeria. Theirs findings indicate that $10.03 \%$ of government constructed ushelter is for the low-income, and the complexity associated with the government housing approach has made it challenging to realize health and economic benefits, including added investments in housing improvement in the area. The study also revealed the challenges in housing in Ekiti to include administrative, institutional and management problems, financial and economic difficulties, physical challenges; and local participatory trials. The sample size of this work is too small for its findings to be generalized. Ndarni and Angbo (2014) reviewed past and present housing delivery policies in Nigeria and suggested approaches to address the issues. The authors opined that a significant consequence of urbanization had been the deterioration of housing conditions in urban centers as reflected in the shortage of housing units and overcrowding. The paper identified causes of housing problems to include poverty, joblessness, natural disasters, overpopulation or ruralurban drift. The authors reflected that there might not be housing shortages in the rural areas of Nigeria or evidence of overcrowding, but many such houses are sub-standard and are lacking in the provision of essential amenities such as pipe-borne water, electricity, sanitary, etc. The housing policies are devoid lackedof technical depth, economic considerations as well as political commitment due mainly to ad-hoc policy formulation for reasonable success achievement, according to the authors. They highlighted positive ways in which government could tackle 
housing problems to include co-operative housing finance, land and planning policy and technology. This study is a mere review and not based on any survey or case study to arrive at the conclusions.

Aduwo et al. (1016) examined urbanization and housing for low-income Nigerians in a non-empirical paper. The author identified the primary drivers of urbanization in Nigeria to include natural population increase, economic and religious activities, state policies, etc., The authors among oting ther issues advocated for the adoption of community-based approaches in the provision of social housing and urban renewal or regeneration as part of future urban housing strategies in Nigeria. The paper, like most of the reviewed articles, is not based on any case study or survey. Thus its conclusions and findings cannot be generalized.

In Osogbo, Osun State, Anthony, Dabara, Joseph, Odewande, and Agidi (2016) studied the challenges of lowincome residential housing delivery. A survey research design was adopted, and 450 respondents were surveyed using systematic random sampling techniquesered were analyzed using descriptive and inferential statistical analytical methods. The study found that the state government has done little or nothing in the area of low-income housing delivery and that a reasonable number or majority of the respondents earn less than N20,000 per month which made it difficult for them to either build or rent a decent accommodation. The study recommended that government should promote increased access to land, reduce interest on housing loan, and subsidize building material prices to make it cheap and affordable for the target groups. The sampling population was intuitively determined. Therefore it cannot be said to be representative of the total study population.

\section{Research Methodology}

Heads of household/landlord in Uyo metropolis constituted the study population. Data from Applied space Technology Laboratory (2016 ASTAL) in Uyo indicated that there is 41,944 residential housing unit in Uyo as at 2016. Kothari formula for sample size determination was used at $95 \%$ level of confidence to determine the sample size which was 380. Uyo metropolis was divided into five (5) significant zones using the major corridors of the city for sampling. Each respondent was identified and sampled through a table of random numbers and administering close-end questionnaires on the respondents, out of which 294 surveys were useable giving an effective response rate of $77.37 \%$. Frequency count and simple percentage were used to analyze the gathered data.

\section{Discussion of Findings}

This section presents the data collected through the administration of questionnaires on the respondents. Asking the respondents about factors leading to poor quality housing in Uyo metropolis, their responses are in Table I below.

Table 1: Factors leading to poor quality housing in Uyo Metropolis

\begin{tabular}{|l|c|c|}
\hline Factors & Response & \% \\
\hline Poverty/Joblessness & 103 & 35.03 \\
\hline Poor Physical Planning & 62 & 21.09 \\
\hline Overpopulation/rural-urban Drift & 68 & 23.13 \\
\hline Non-access to land & 16 & 5.44 \\
\hline Inadequate urban infrastructure & 45 & 15.31 \\
\hline
\end{tabular}

Source: Author's field Survey

Data in Table I above shows that 103 respondents representing $35.03 \%$ were of the opinion that poverty and joblessness is the leading cause of living in low-quality housing as they could not afford houses with better amenities. The table further shows that $68(23.13 \%)$ respondents viewed over-population resulting from ruralurban drift, as the leading cause for the respondents resorting to low-quality housing, while $62(21.09 \%)$ respondents saw poor physical planning as the leading factor. Also, 45 (15.31\%) respondents viewed inadequate urban infrastructure, while $16(5.44 \%)$ respondents viewed non-access to land as the cause. These findings collaborate the research findings of Jiboye (2011), Ndarni and Angbo (2014) and Aduwo et al. (2016) where poverty, joblessness, natural disaster, overpopulation or rural-urban drift were the leading cause of housing problems in Nigeria.

Asking the respondents about the household problems they experienced as a result of the inadequate quality housing, their responses in table 2 below. 
Table 2: Household problems experienced/encountered by the respondents in Uyo

\begin{tabular}{|l|c|c|c|c|}
\hline Problem & Affected & \% & Not affected & \% \\
\hline Lack of ventilation & 161 & 54.76 & 133 & 45.24 \\
\hline Congestion & 212 & 72.11 & 82 & 27.89 \\
\hline Lack of Privacy & 184 & 62.59 & 110 & 37.41 \\
\hline Indoor pollution & 219 & 74.49 & 75 & 25.51 \\
\hline Noise & 154 & 52.38 & 140 & 47.62 \\
\hline House pests & 177 & 60.20 & 117 & 39.80 \\
\hline Insecurity & 149 & 50.68 & 145 & 49.32 \\
\hline Crimes & 156 & 53.06 & 138 & 46.94 \\
\hline Leaking roofs/floors & 123 & 41.84 & 171 & 58.16 \\
\hline Coldness & 98 & 33.33 & 196 & 66.67 \\
\hline
\end{tabular}

Source: Author's field Survey

Household problems experienced by the respondents as shown in Table 2 above reveals that majority of the respondents (54.75\%) are affected by lack of ventilation on their apartment. Also, 212 respondents representing $72.11 \%$ are affected by congestion, while $62.59 \%$ of the respondents lack privacy in their apartment. Reduced congestion and confidentiality are as a result of so many persons living in a smaller apartment. The table further indicated that $74.49 \%$ of the respondents suffer indoor pollution as a result of fumes from generators, and $52.38 \%$ of them suffered noise pollution given the nature of their neighborhood with commercial land use. House pests constitute a challenge to $60.20 \%$ of the respondents, while $50.68 \%$ and $53.06 \%$ of the respondent respectively are affected by insecurity and crimes in the neighborhood respectively. The table also reveals that $58.16 \%$ and $66.67 \%$ of the respondents respectively are not affected by leaking roof/flours and coldness respectively. The studies of Ononugbo et al. (2010) and Cheserek and Opata (2011) collaborates the above findings.

The researcher sought to understand the environmental problems encountered by the respondents in Uyo as a result of living in a slum area. Asking the respondents about possible issues identified in the literature, their responses, in table 3 below.

Table 3: Environmental problems experienced/encountered by the respondents in Uyo

\begin{tabular}{|l|c|c|c|c|}
\hline Problem & Affected & $\mathbf{\%}$ & Not affected & \% \\
\hline Garbage/Solid Waste & 247 & 84.01 & 47 & 15.99 \\
\hline Poor drainage & 239 & 81.29 & 55 & 18.71 \\
\hline Water pollution & 195 & 66.33 & 99 & 33.67 \\
\hline Air Pollution & 182 & 61.90 & 112 & 38.10 \\
\hline Liquid waste & 186 & 63.27 & 108 & 36.73 \\
\hline Flooding & 131 & 44.56 & 163 & 55.44 \\
\hline
\end{tabular}

Source: Author's field Survey

The above table 3 shows that $84.01 \%$ of the respondents had garbage/solid waste as environmental problems in their neighborhood while $81.29 \%$ of the respondents identified poor drainage as ecological problems in their area. From the table also $66.33 \%$ and $61.90 \%$ of the respondents respectively suffered water pollution and air pollution respectively as environmental problems in their field, while $63.27 \%$ of the respondents identified liquid wastes as an ecological problem they experienced in Uyo. Majority of the respondents (55.44\%) are not affected by flooding problem in Uyo metropolis while $44.56 \%$ are adversely affected. Again the findings of this research are collaborated by the conclusions of Ononugbo et al. (2010), Cheserek and Opata (2011) and Aduwo et al. (2016). The respondents were next asked to identify diseases commonly affecting them in their neighborhood and table 4 below present their responses.

Table 4: Diseases identified by the respondents in Uyo

\begin{tabular}{|l|c|c|c|c|}
\hline Diseases & Affected & $\mathbf{\%}$ & Not affected & \% \\
\hline Malaria & 264 & 89.80 & 30 & 10.20 \\
\hline Cough/Chest Pain & 207 & 70.41 & 87 & 29.59 \\
\hline Typhoid & 192 & 65.31 & 102 & 34.69 \\
\hline Diarrhea & 153 & 52.04 & 141 & 47.96 \\
\hline Cholera & 132 & 44.90 & 162 & 55.10 \\
\hline Eye Infection & 124 & 42.18 & 170 & 57.82 \\
\hline
\end{tabular}

Source: Author's field Survey

Typhoid influences table 4 above shows that $89.80 \%$ of the respondents are affected by malaria, while $70.41 \%$ are affected by cough/chest pain and $65.31 \%$ of the respondents. These diseases are prevalent in these areas because of the unfortunate nature of the neighborhood. This position also supports earlier findings in table 3 where the respondents indicated that they encountered environmental problems such as garbage, poor drainage, water and air pollution which can lead to these diseases. The table 4 also reveals that $52.04 \%$ of the respondents are 
affected by diarrhea while $44.90 \%$ and $42.18 \%$ of the respondents respectively are affected by cholera and eye infection respectively. The research findings of Ononugbo et al. (2010), Cheserek and Opata (2011), Aduwo et al. (2016) and Anthony et al. (2016) support the findings of this study.

\section{Conclusion}

This paper has examined the impact of housing quality on the low-income households in Uyo. It has explored factors leading to living in poor quality houses and environmental/health problems encountered by such persons. The study concluded that poverty and joblessness were the leading factors why residents in Uyo metropolis choose to live in low-quality housing. It also found that residents in Uyo suffered several environmental problems such as garbage, poor drainage, water pollution, air pollution and liquid waste and as a result, they tend to suffer diseases such as malaria, cough, typhoid, diarrhea and eye infection.

The state government should consider the up-grading of areas such as Urua-Ekpa-Itu Road axis; Udosen UkoIfa Street; Oron-Ikot Ekpene-Abak-Aka Roads within the central business district of the state capital through urban renewal programmes. There should be a revitalization of the abandoned social housing scheme for the public, especially the one for the low-income earners.

\section{References}

Aduwo, E.B., Edewor, P.A. and Eziyi, O. I. (2016). Urbanization and Housing for Low-Earners in Nigeria: A Review of Features, Challenges, and Prospects. Mediterranean Journal of Social Science, 7 (3): 347-356.

Anthony, A. I., Dabara, D.I., Joseph, O. Odewande, A.G., and Agidi, O. M. (2016). Low Income Residential Housing Delivery in Osogbo, Osun State, Nigeria, Conference of the International Journal of Arts of Science, 9(1):15-28.

Basorun, J. O., and Fadairo, G. (2012). Government Challenges in Housing the Urban Poor in Ado-Ekiti, Nigeria. Journal of Sustainable Society, 1 (2):31-35

Cheserek, G.J. and Opata, G.P. (2011), Environmental and Housing Problems of Low-Income Households in Eldoret Municipality, Kenya. Journal of Emerging Trends in Economics and Management Sciences, 2(4):320-324

Jiboye, A.D. (2011). Urbanization Challenges and Housing Delivery in Nigeria: The need for a practical policy framework for Sustainable Development. International Review of Social Sciences and Humanities, 2(1):176185.

Koleoso, H.A., and Adeyinka, A. (2006). Impact of Environmental Degradation/Slum on Youth Growth and Development: a Case study of Iwaya Community Lagos State, being a paper presented at International Conference on Environmental Economics and Conflicts Resolution, University of Lagos, Lagos $25^{\text {th }}-28^{\text {th }}$ July.

Ndarni, G.G., and Angbo, Y.B. (2014). Sustainable Housing for Poor People in Nigerian Urban Areas. World Journal of Building Technology and Estate Management, 1(1): 6-9.

Ononugbo, V.I., Akpan, I.A., Osho, G.S., and Kritsumis, W.A. (2010). Housing Needs for the Low-Income People of Enugu Metropolitan Areas of Nigeria: Policy Issues and Challenges. International Journal of Management, Business, and Administration, 13 (1):1-41.

Ross, T., Parsons, C., and Vallas, R. (2016). Creating safe and Healthy Living Environment for Low-Income Families. Available at www.americanprogress.org retrieved on 20/12/2017. 